\title{
The Giant Who Had No Heart
}

\section{Adapted and written by Laura Simms}

\begin{abstract}
Norway is wealthy in natural resources, mountains, lakes and forests. There are few poor people in Norway. Some of the largest humanitarian organizations in the world, dedicated to promoting justice and children's rights are located in the capital city of Oslo where there is a fairytale castle guarded by charming guards in colourful costumes in a great park. Here, the King and Queen of Norway live. They sponsor festivals and marvelous events for children every year.
\end{abstract}

Special note to storytellers before beginning this story. In this tale there is Giant. You and the children can decide what wishes you would like to make for one another so that no giants lurking hidden in any nightmares or secret thoughts can enter the room. Let each child who makes a wish be the caller. Let the group repeat the wish in a loud call-and-response format. Go around the circle hearing all the wishes. Then begin telling The Giant Who Had No Heart.

T there was once a King who had seven sons. The King did not like to be alone. So when it was time for the princes to go out into the world and find brides, the King said, "One son must remain with me." The eldest son insisted that the youngest stay at home saying, "our youngest brother is a fool. He sits all day by the hearth with nothing on his mind, and ashes on his shoulders. Let him stay." The King agreed. He ordered the six young men to bring back seven brides, one for the youngest, and gave them six strong horses and bags of gold for the journey.
In time the princes found six brides and set off toward home forgetting about their youngest brother. As they traveled they got lost in a thick forest. They found themselves in front of a stone castle owned by a giant. As soon as the Giant saw the six well-dressed princes and their six brides on six strong horses, he turned them into stone.

The king and the youngest prince waited, but the brothers did not return. Finally, the prince asked, "Why not let me go out and search for my brothers?" At first the king refused, but finally he agreed. He said, "if there is another strong horse in the stable you can ride out to find your brothers."

However, there was only a skinny, aging, decrepit horse barely able to stand. Its back was caved in and its legs shook.

"You can not travel on that horse," said the King.

"I will take the horse," replied the ash boy as he placed a well-worn saddle on its back and climbed upon the horse. He rode away. His horse rode slower than a three-legged horse. He had no idea what direction to travel, so he followed his heart and soon arrived at the outskirts of a thick vast forest.

A wounded raven lay trembling on the earth. Its wings were torn and its eyes were dull. "Please," begged the raven, "give me something to eat." The prince pitied the bird and crumbled half of the bread he carried to feed the raven. Instantly the bird's wings grew strong and shiny, its body grew sleek, its eyes bright and the raven flew away.
Entering the forest, the price grew thirsty. But when he bent to drink from a stream, he heard a pitiful sound. A salmon lay on the earth beside the water shaking. Its mouth opened and closed as it sought water. It said, "Please throw me into the stream." The ash boy lifted the salmon and placed him in the water and watched his body gain strength and swim away.

$\mathrm{He}$ rode on, until a wolf half starved and barely able to stand came out from behind a tree. Its stomach was so thin the prince saw his ribs as if the beast was made of crystal. A wind blew and the wolf shook like a leaf.

"Please, I have not eaten for two years. Give me some food."

The prince said, "I can give you the rest of my bread." "No," answered the wolf, "please give me your horse to eat." "If I give you my horse, how will I travel?" said the Prince.

"You can ride on my back," said the wolf.

Taking pity on the wolf, and knowing that the horse was nearly dead, the Prince climbed to the ground. The horse neighed and lay down relieved to rest at last. The starving wolf made a feast of the flesh. Instantly the wolf grew plump, his fur shone, his eyes glowed and his tail swayed back and forth with happiness. "Climb on my back," said the wolf. The prince rode on the wolf's back. "Where are we going?" asked the creature. "I do not know. I seek my six brothers who are lost." The wolf set off. He rode fast than a four-legged horse. Before long they arrived at a stone castle before which stood 18 stones.

"These are you brothers and their horses and their brides," said the wolf. "What shall I do?" asked the Prince. "Inside the cas- 
tle is a princess. Do all she says," answered the wolf. The wolf raced away back to the forest, calling out, "When ever you need me just call for me."

The Prince entered the castle. Inside sat a desolate princess. She said, "Only a fool would enter this castle." The prince said, "I have been called a fool."

She warned, "I am a prisoner of a giant who can't be killed because he has no heart." "How can anything that lives have no heart? It must be somewhere," inquired the prince. "His heart must be hidden," said the princess. "Can you ask?" replied the prince. "The stones outside are my brothers and their brides."

"Hide under the bed," commanded the princess. And it was just in time because the giant returned to the castle.

He roared, "I smell a human being." The princess said, "Your nose is sensitive. Someone passed by three hours ago, but there is no one here now." The giant laughed. And they sat down to dinner.

Afterward the giant sat on the bed and said, "Tell me a story."

The princess said, "Perhaps tonight you can tell me a story. Tell me why you hide your heart?"

"If anyone was to find my heart, they could kill me."

The princess said, "I would never kill you." And she asked again and again, until the giant, said "All right, my heart is beneath the stones of the threshold of the door to the castle." And he fell asleep.

In the morning the giant left the castle to go to the forest. The Prince came out from under the bed. He and the princess took up the stones and dug beneath the threshold, but found no heart.
They placed the stones as they had been and gathered flowers. The princess placed them on the threshold so it looked untouched. Then she ordered the prince to hide under the bed just as the giant returned.

"I smell human again," he roared. "A crow dropped a small bone in the chimney," she explained. "What are the flowers doing on the floor?" said the giant.

"I placed them there because you said it was where you kept your heart," she responded. The giant shouted happily, "I lied. My heart is not beneath the door." "Tell me where your heart is kept," she asked as they sat on the bed after dinner. "It is in the kitchen cabinet," he answered.

The next morning when the giant went to the forest, the prince and the princess looked in the cabinet but there was no heart. She covered the door with flowers.

Again the giant thought he smelled a human and again she told him it was only a bone dropped by a bird and he asked about the flowers.

"Is it not the place where you heart is kept? I wanted to honor the special place."

"My heart is not in the cabinet." He laughed and asked for a story. That night she asked again about his heart. At last the giant said, "Since you can never leave this house and will not find it, I will tell you. What harm can it be?"

He explained, "There is a lake far away. In the middle of the lake is an island and on the island is a tall tower. In the tower is a deep well. In the well is a duck and in the duck is an egg. In the egg is my heart." And the giant fell asleep.

After the giant departed, the princess said, "It will be impossi- ble to find the lake." The prince said, "I will try my best."

Outside he called for the wolf who raced to his side. He climbed on the wolf's back and told him where the giant's heart was held.

"I do not know the way, but I will find it," said the wolf. The wolf raced like the wind and stopped by the edge of a lake very far away.

The prince said, "I cannot swim."

"Hold tight," said the wolf as he dove into the water and swam to the island with the prince on his back. The tower loomed as high as a mountain above them. Way on the top was a tiny key.

"How can I reach the key?" sighed the Prince.

And the wolf said, "Call for the raven that you fed."

The raven flew to the island from the forest, took the key in its beak and gave it to the prince, who opened the door of the tower. Inside was an ancient well. Standing on the wolf's back the Prince peered into the water. $\mathrm{He}$ saw a female duck swimming round and round. $\mathrm{He}$ watched until his eyes knew the rhythm of the bird and then caught her in his hands, pressing her belly firmly. But the duck squeezed loose flying above, dropping the egg. The prince caught the egg in his hands, but was so startled that he dropped it back into the well and watched it sink.

"What shall I do?" He said as the duck disappeared in to the distance.

"Call for the salmon that you saved," said the wolf. The salmon rose up from the bottom of the well with the egg on its back. The prince took the egg with the giant's heart in his hands. 
"Now what shall I do?" inquired the prince.

"Squeeze the egg," said the wolf. And the prince did.

The giant's scream pierced the sky, "Do not squeeze my heart!"

"Squeeze his heart again," urged the wolf.

"Stop," shouted the giant. "I will do anything you want. Just don't squeeze my heart."

"Squeeze it again," said the wolf.

This time the giant begged for mercy and the prince called out, "I will not squeeze your heart if you turn my brothers, their brides and the horses back from stone." And the giant turned them back to life.

"Squeeze the heart again," commanded the wolf. And the prince squeezed the heart.

The giant called out, "You said you would not squeeze my heart!"

The prince said, "Set the princess free." And the giant set her free.

"What shall I do with the heart?" asked the Prince.

The wolf answered, "That is up to you."

So the Prince climbed on the wolf's back and returned to the castle. Outside his brothers sat on their horses with their brides. The giant shook from head to toe in fear. The prince placed the heart in the giant's chest.

The giant began to weep as he watched the princess climb on the wolf beside the prince. He said, "I am sorry. I wanted you to stay with me forever."

The princess said, "You shall serve our kingdom and all the people and the creatures of the forest that you harmed, as you were meant to do."
So it was that the giant with a heart became the guardian of the forest and protector of the castle. The youngest prince married the princess and became the new king and the queen. The six princes and their brides married as well and served the Royal house and all the world. The trees were filled with ravens and the streams were thick with salmon. The wolves were well fed, and everyone lived happily ever after.

\section{Storyteller's Notes 1}

Even a dog's tooth emits light - Tibetan Proverb ${ }^{2}$

- This story awakens the experience of caring for others within each listener, even though others may be different and even when there is no potential for gain. Through spontaneously helping the raven, the salmon, and the wolf, the prince gained unexpected allies during his quest. The listener, who in bringing the tale to life in their mind, becomes both the helper and the helped in their imagination, and gains the self ally of learning to trust compassion.

- Through identification with the character of the Giant, children begin to realize their intrinsic goodness. The Giant was not uncaring by nature, he merely needed to regain his heart.

- During this story and activity, build on children's coping skills to help them manage whatever anxiety is elicited. Working on fears indirectly- through the giants and monsters that inhabit tales - is an important step toward mastery.

The Giant Who Had No Heart is a classic fairy tale of a hero who overcomes great obstacles through natural kindness and intuition and saves his Kingdom and the natural world. He brings the heart back into power and the Queen back into the place of shared rulership. The central characters of the story are a Giant who has no heart in his body; and a boy who acts solely from the heart; a Queen who is not present; a princess who has been kidnapped and held prisoner by the giant; and a duck that is in the well in a tower and has the heart of the giant in her body. There are four main animals; a weak old horse, a raven, a salmon, and a wolf. And there is a King who cannot bear to be alone, and six selfish brothers who get turned to stone with their six brides and six horses.

The misfortune befalling his brothers brings the youngest "dreamer" out of his hideaway by the hearth. He agrees to ride a horse that can barely travel, and feeds three animals (one of the air, one of water, and one of earth). By giving up the horse he depends on and feeding it to the wolf, he receives the means to travel into the giant's forest and the instructions serve him. Befriended by the princess, he learns about the dishonesty of the giant, the intelligence of the princess and where the giant keeps his heart. The impenetrable section of the forest is a prelude to a journey further into a symbolic realm: across the water to an island to the tower and the well where the duck holds the heart of the Giant. The youngest brother cannot succeed on his own. And, because of his past goodness, he is helped by all and is able to retrieve the heart.

Children of all ages love this story because it is rich with meaning and they identify with everyone. I have learned from children that they identify both with the giant and with the prince. The giant is able to hide his heart, which many children have themselves learned to do. Uniting inner parts 
of themselves, the female that is captured and the male that is undeveloped, children undergo a ceremonial process of reclaiming their own hearts and deciding what to do with it.

In this version, different than the classic Norwegian version, the boy puts the heart back in the giant who is instantly transformed. What was absent is now recovered and with that his emotional life and sense of responsibility for other. The giant releases the princess, and protects the kingdom as well as the natural world. This is a remarkable lesson to be ingested by our children. Regardless of what or who we have been in the past, we can become normal even "soulful" - protecting ourselves and our personal kingdom.

The activities that follow help children acknowledge their fears and assist them to gain more control over them. Naming our fears in a metaphorical way - like giving titles to monsters and giants aerates things unseen and unmentionable. Monsters may represent natural forces, or purveyors of extreme power coupled with little conscience or heart. Done in a playful way, the child is practicing control over their own minds where fears lurk long after they are dangerous in reality. This activity helps children make friends with their nightmares, and begin to sidestep that most tragic of dramas - the self induced creation of past things feared.

In this tale there is a Giant. You and the children can decide what wishes you would like to make for one another so that no lurking giants can enter the room. Let each child who makes a wish be the caller. Let the group repeat the wish in a loud call-and-response format. Go around the circle hearing all the wishes. Then begin telling The Giant Who Had No Heart.

\section{Art Activity - Lighting Up the Heart of the Forest}

\section{Art Materials}

$\checkmark$ Two pieces of $81 / 2^{\prime \prime} \times 11$ white paper per child

$\checkmark$ Tape

$\checkmark$ Magic Markers, crayons, paint (if appropriate to the age group)

$\checkmark$ Scissors

$\checkmark$ Small flashlight

$\checkmark$ Strong string

$\checkmark$ Hole punch (optional)

\section{Directions}

- Each child should lay out the two pages horizontally, and then tape them strongly together in the middle, making one page.

- Ask them to colour a panoramic painting with forest fauna, animals, flowers, leaves. Suggest that they use a lot of color and shape. Encourage them to fill the page, making sure they use only one side of their paper.

- On the top of the page make little holes every few inches.

- Tape the open sides of the pages together strongly with the coloured painting on the inside.

- Taking the string, make a hanging loop. You now have a lantern that hangs from the top, with the bottom open. Holding it up you can not see anything but the shadows of the images.

- To transform the lantern, shine a flashlight on the inside. Just as the giant, when his heart is returned, protects and keeps the forest alive, the children will see their vivid, bold, and colorful landscape come to life and begin to illuminate all around it.

Note: You can remind children that they themselves are like lanterns when they listen to a story. Their insides are alive with color and image as they listen, bringing the tale to life.
Related Study Ideas:

This tale presents many topics that can be explored together: the life of the forest, the shapes and lives of the animals, the role of our hearts in shaping our lives and those around us, the structure of a kingdom, and the positive nature of leadership. There is a universe within this story that can be explored with your children.

\section{Writing Activities}

The first writing activity for The Giant Who Had No Heart is called Making a Monster. This exercise, as with all the writing exercises, begins with preparatory questions; which is how writers work. This will provide children with a rich resource of options to draw from when they begin their stories.

- Each of you is going to create a monster. Describe the worst monster you can imagine. Include all the details you can invent to make up a terrible giant, or creature.

- Write down all the powers that your monster might have, and how the monster uses those powers. Example: the monster might have fingers that turn into knives, of the ability to blow storms from its breath, or a hundred heads, and so on.

- Describe the landscape where the monster lives.

- How does the monster use his or her powers for destructive reasons?

- How could the monster use the same powers in a positive way, if the monster was transformed and had his heart back?

\section{Optional, time permitting:}

Create the history of how the monster got to be as terrible as you have described. What happened to the monster? Give the monster a history. 
- Identify a literal object that could have a very special magical power for you. It might be a seashell, or a keepsake from a family member or friend. It doesn't matter what it is, what matters is what it means to you.

- Next choose an animal that is or can be a helper, guide, and personal friend to you.

- Write the story of how and why the monster wants to steal your magic object. And how you, with the help of you animal guide, set out on a journey to get back the object, and save the world by transforming the monster to use his power for good.

Note: Perhaps nothing is as important as discovering that what is the worst could become the best. Having a history of the monster helps develop a realization that there are often reasons behind someone's behaviours, including our own. At any time, you can ask the children to read a few of their segments aloud. Remind them that the segments do not have to be narrative, but can be lists.

\section{Map Exercise}

1. Say out loud the name of the country you are learning about.

2. Find out the country on the map and look to see if it is east, west, north, or south of where you are now. Is the country on the sea, or is it landlocked? Where a country is situated tells us a lot about that country. What do you think this information tells us?

3. What do you know about traveling to and from this country, judging from its location on the map? How is this similar to (or different from) where you live?

4. What animal, whether, and/or detail of landscape from this country is mentioned in your story?

5. After hearing the story, what do you think people care about in this country? Is this different from what you care about in you country?

\section{Sharing the World Activities}

Before the era of heating and electric lights, Norwegians had to come up with ways to deal with the freezing temperatures and prolonged darkness of their winters. During the cold months, the average temperature is near or below zero, and daylight might last for only a few hours. Remembering your own experience with black-outs or harsh weather like blizzards, what do you imagine Norwegians did to cope with their climate and very short days?
How do you think stories helped Norwegians cope with the long winters, when they had to spend weeks on end inside together?

\section{Notes}

1. Please note that the richness of meaning possible within each story is not limited to those highlighted in the notes offered.

2. The possible meanings of this interesting proverb are a good source of conversation.

\section{Bibliography}

Booss, Claire. (editor). 1984. Scandinavian Folk And Fairy Tales. New York: Gramercy Books.

Dorson, Richard M. 1975. Folktales Told Around The World, Chicago and London: University of Chicago Press.

Leonard, Linda Schlerse. 1995. Creation's Heartbeat: Following The Reindeer Spirit, New York: Bantam Books.

\section{- \\ Basic Tips to Telling Tales}

\section{Preparation}

\section{Speak from the heart}

Read the story out loud to yourself at least twice, or to a friend. Talk about the tale.

Remember the story, don't memorize the story

Make an outline of the events.

Visualize the landscape of the story

Draw a map of the landscape.

\section{Practice}

Tell the story to a friend, spouse or child.

\section{Use the past tense}

When a story is told in the past tense it is clear the story didn't happen to the teller, that the teller is merely recounting a story. The listeners will turn it into the present as they listen.

\section{Inform yourself}

Find out about objects, symbols, plants, and places in the story.

\section{Don't take sides}

The difficult characters move what is stuck or unbalanced so that the narrative can't go forward. Fall in love with the worst characters and appreciate how they affect the outcome.

\section{Return to text}

Read it again and let the feelings of the story touch you.

\section{Before Telling the Story}

$\checkmark$ Decorate and rearrange the room to make it more comfortable and welcoming.

$\checkmark$ Take a deep breath before you begin.

$\checkmark$ See the room and the children you are about to speak to. 
$\checkmark$ Help yourself and the children settle down for listening.

$\checkmark$ If you are nervous, don't fight your discomfort but appreciate it. Begin anyway, your vulnerability will help your audience appreciate their own.

$\checkmark$ Remember the end of the story so you recall where you are going. Just forget the words and begin as if you were telling someone how you walked to work this morning.

\section{Telling the Story}

The best teller is you

Not a character in the story.

The storyteller is a guide

Not an actor or instructor. Meaning is felt more deeply than understood.

Speak directly to you listeners

Use you natural voice.

Pace yourself

Words travel from your mouth to the heart of the listener where im- age and feeling arise. Don't be afraid of pauses.

\section{Let the story penetrate you}

but do not act out the emotions you feel.

\section{After Story is Ended}

$\checkmark$ Let a moment pass before you speak and experience the feeling tone in the room.

$\checkmark$ See your audience again.

$\checkmark$ Make sure there is a true end like "and that is that!" or "The story is ended."

$\checkmark$ Questions that have no necessary answers are best: how did you feel? What happened while you listened? Anyone have any questions about the story? Allow all answers to come forth. Your role is now to listen and encounter surprise.

Be honest about what you might not understand

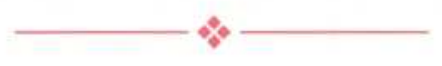

Laura Simms is a New York based, world renowned professional storyteller. She is a spokes-

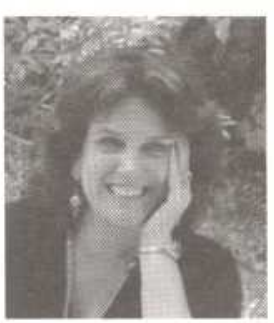
person for the revival of the oral tradition and has been appointed as resident artist for the Lincoln Center Institute for Aesthetics and Education for a term

of three years. Her recent work with Mercy Corps in the wake of the New York trade Center tragedy brought hope to thousands of traumatized children. As Director of the Gaindeh Project an international storytelling for survival iniutiative she has captured the hearts and souls of listeners and tellers world wide. Several CD's and many books make Laura Simms a prestigious contributor to Teaching and Learning. For more information about Laura contact: www.laurasimms.com

\section{Storytelling in Schools Program and Other links}

Readers may not be aware that there are many storytelling associations or guilds located in Ontario and across Canada. Check local listings for information in your region.

An important resource for Teachers is the Storytellers School of Toronto. It is a non -profit charitable organization focusing on support for storytellers and listeners and encouraging an appreciation for literary arts and an understanding of the relationship between writing, reading, storytelling and performance.

Critical is its commitment to celebrating the richness of storytelling traditions of different cul- tures and encouraging children and youth to develop their own storytelling skills as storytellers.

The school teachers courses on storytelling and provides workshops and storytellers to school children through a special events, festivals and performances.

The school co publishes Apple Seed, a quarterly publication, in collaboration with Storytellers of Canada-Conteurs du Canada and Pippen a newsletter that informs members and the public about storytelling events and happenings.

The web site contains information on how to access the Sto- ryteller in the Schools Program sponsored by Ontario Arts Council and arrange performances and workshops for pre-school, elementary, high school and multifaith-community groups and charity organizations. The site includes links to resources and other storyteller sites.

Visit The Storytellers School of Toronto at

www.storytellingtoronto.org

Or contact Marylyn Peringer,

Resident Teacher at

416-656-2445

43 Queen's Park Crescent

Toronto, Ontario M5S 2C3 